\title{
VENTRICULAR ARRHYTHMIAS INDUCED BY AMINOPHYLLINE DURING HALOTHANE ANAESTHESIA IN DOGS
}

\author{
MasuHiro Takaort, M.D., PH.D., ANd Robert W. Loehning, M.D., PH.D.`
}

INTRAVENOUS AMTNOPHYLIINE and sympathomimetic amines have been advocated for treatment of asthmatic attacks during anaesthesia. ${ }^{1-5}$ Halothane, an agent which sensitizes the heart to certain sympathomimetic amines, has been shown to be a valuable agent for anaesthetizing patients with an asthmatic history. ${ }^{5}$

The administration of caffeine and theophylline intravenously to dogs anaesthetized with pentobarbital may lead to ventricular arrhythmias in the presence of catecholamines. ${ }^{0,7}$ In clinical use aminophylline has been reported to have produced arrhythmias and cardiac "collapse" when administered intravenously. .10 $^{\text {-10 }}$ During the course of animal studies in which sympathomimetic amines and aminophylline were administered during halothane anaesthesia it was noted that a number of animals developed arrhythmias after aminophylline injection.

It was the purpose of this study to determine the incidence and severity of arrhythmias following aminophylline in awake dogs and in dogs anaesthetized with halothane, barbiturates, or ether. The effect of combinations of aminophylline and sympathomimetic amines during halothane anaesthesia has been reported previously. ${ }^{11}$

\section{METHOD}

Adult mongrel dogs premedicated with morphine $(0.2 \mathrm{mg} . / \mathrm{kg})$ and scopolamine $(0.01 \mathrm{mg} . / \mathrm{kg}$.) or atropine $(0.02 \mathrm{mg} . / \mathrm{kg}$.) were induced with thiopental (13.6-20.0 mg./kg.) and suxamethonium $10 \mathrm{mg}$. and intubated with a cuffed endotracheal catheter. Ventilation was maintained with a Palmer Ideal Pump using sufficient volumes of room air to maintain end tidal $\mathrm{P}_{\mathrm{CO}_{2}}$ at $34-38 \mathrm{~mm}$. $\mathrm{Hg}$, monitored with an infrared $\mathrm{CO}_{2}$-analyser. Two ml. of 1 per cent lidocaine was used in dogs in the unanaesthetized group for placement of femoral catheters. Pentobarbital, chosen as the agent for the group with barbiturate anaesthesia, was given in just sufficient dosage to keep the animals from struggling (22.4$39.1 \mathrm{mg} . / \mathrm{kg}$. in 60-90 minutes). Ether and halothane vapourized with oxygen in a "copper kettle" and a "Fluotec" respectively were administered by a nonrebreathing system.

\section{Unanaesthetized Group}

Ten premedicated trained dogs were given aminophylline $50 \mathrm{mg} . / \mathrm{kg}$. by constant injection within four minutes. Heart rate increased from $110 \pm 24.6$ to $130 \pm$ 52.6. Multifocal premature ventricular contractions (M.P.V.C.) lasting several seconds appeared in one animal and sinus tachycardia (S.T.) developed

-Division of Anesthesiology, College of Medicine, University of Utah, Salt Lake City, Utah. Dr. Takaori's present address is Department of Anesthesiology, University of Osaka, School of Medicine, Osaka, Japan. 
TABLE I

ARrhythmias following AMinophyLline

\begin{tabular}{|c|c|c|c|c|c|c|}
\hline \multirow[b]{2}{*}{$\begin{array}{c}\text { Anesthesia } \\
\text { group }\end{array}$} & \multirow[b]{2}{*}{$\begin{array}{l}\text { No. } \\
\text { dogs }\end{array}$} & \multicolumn{5}{|c|}{ Arrhythmias } \\
\hline & & None & $\begin{array}{c}\text { Sinus } \\
\text { tachycardia }\end{array}$ & $\begin{array}{c}\text { Premature } \\
\text { ventricular } \\
\text { contraction }\end{array}$ & $\begin{array}{l}\text { Ventricular } \\
\text { tachycardia }\end{array}$ & $\begin{array}{l}\text { Ventricular } \\
\text { fibrillation }\end{array}$ \\
\hline $\begin{array}{l}\text { Unanesthetized } \\
\text { Barbiturate } \\
\text { Ether } \\
\text { Halothane } 3 \% \\
\text { Halothane 1\% }\end{array}$ & $\begin{array}{r}10 \\
9 \\
6 \\
6 \\
16\end{array}$ & $\begin{array}{l}1 \\
2 \\
1 \\
5 \\
1\end{array}$ & $\begin{array}{l}\mathbf{8} \\
\mathbf{7} \\
\mathbf{3} \\
\mathbf{1} \\
\mathbf{3}\end{array}$ & $\begin{array}{l}1 \\
0 \\
2 \\
0 \\
4\end{array}$ & $\begin{array}{l}\mathbf{0} \\
\mathbf{0} \\
0 \\
0 \\
\mathbf{5}\end{array}$ & $\begin{array}{l}0 \\
0 \\
0 \\
0 \\
3\end{array}$ \\
\hline
\end{tabular}

Arrhythmia listed is the most severe occurring in each animal.

in eight other animals (Table I). Arterial pressure changes following aminophylline were inconsistent, with increases of not over $10 \mathrm{~mm}$. $\mathrm{Hg}$ and decreases of not more than $35 \mathrm{~mm}$. Hg (Fig. 1).

\section{Barbiturate Group}

When heart rate and arterial pressure became stable (60-90 minutes) after induction with pentobarbital, aminophylline $50 \mathrm{mg} . / \mathrm{kg}$. was given to nine dogs. Heart rate increased $81 \pm 40.2$ from $175 \pm 34.3$, and arterial pressure decreased $40 \pm 23.9$ from $147 \pm 2.13 \mathrm{~mm}$. Hg (Fig. 1). Arrhythmias did not occur.
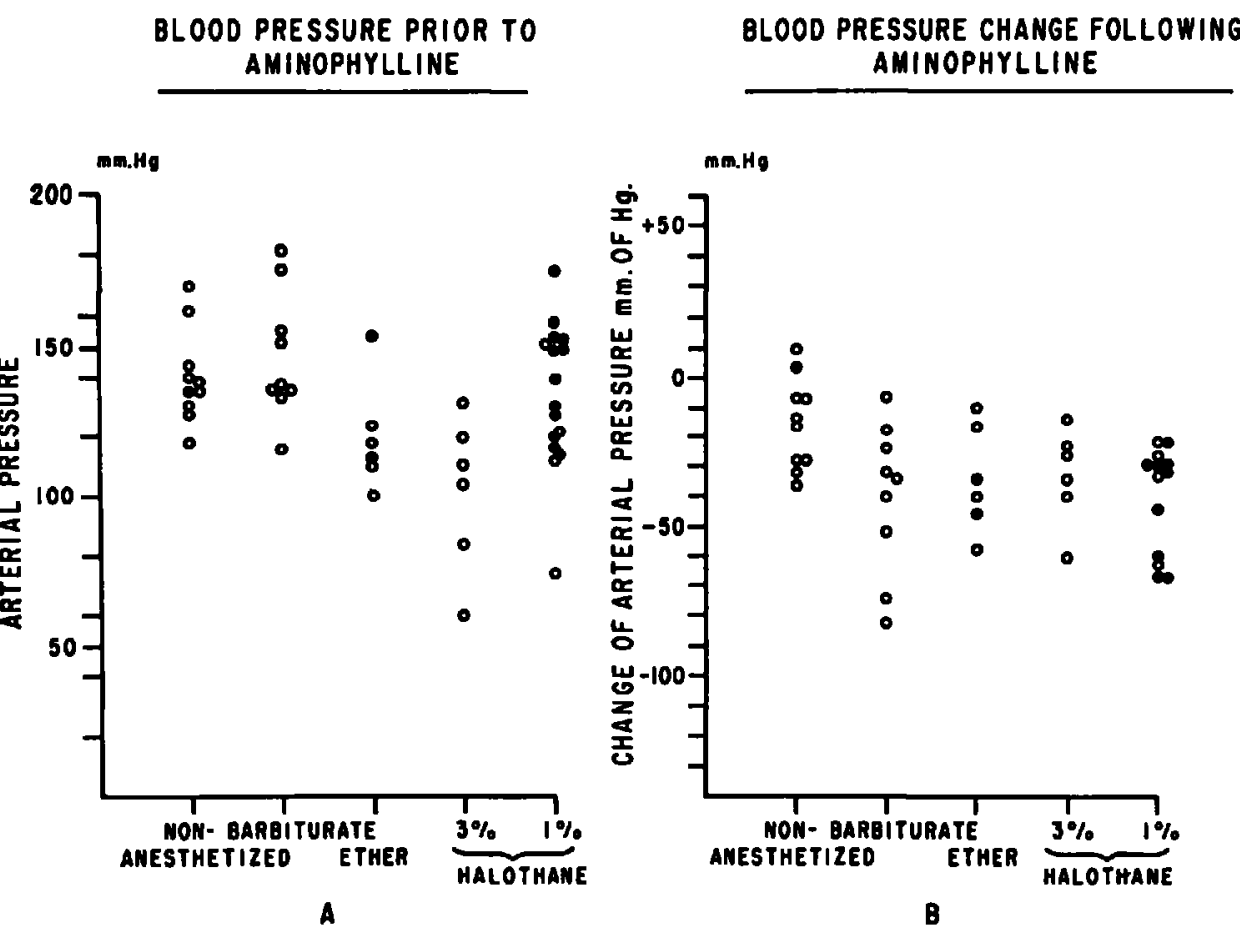

Figure 1. Blood pressure level prior to aminophylline is shown in graph $A$ and changes in $\mathrm{mm}$. $\mathrm{Hg}$ following aminophylline are shown in graph B. Key: $=$ ventricular arrhythmias; $\mathrm{O}=$ no arrhythmias. 


\section{Ether Group}

Six dogs were ventilated with 3 per cent ether for 30 minutes and were then given aminophylline $50 \mathrm{mg} . / \mathrm{kg}$. Heart rate increased $54 \pm 29.2$ from $157 \pm 36.5$ and arterial pressure decreased $32 \pm 15.1$ from $116 \pm 23.9 \mathrm{~mm}$. $\mathrm{Hg}$ (Fig. 1). M.P.V.C. appeared for three minutes in one animal and for seven minutes in another (Table I).

\section{Halothane 3 Per Cent Group}

Six animals were ventilated with halothane 3 per cent for ten minutes and were then given aminophylline $50 \mathrm{mg} . / \mathrm{kg}$. Heart rate increased $23 \pm 16.9$ from $137 \pm 26.5$ beats/minute and arterial pressure decreased $33 \pm 16.2$ from $102 \pm$ $24.0 \mathrm{~mm}$. Hg. Arrhythmias were not found after aminophylline while the animals were being ventilated with 3 per cent halothane. However, when the dogs were subsequently ventilated with room air and were in a lighter plane of anaesthesia, two animals developed unifocal premature ventricular contractions (U.P.V.C.), one developed M.P.V.C., and one other had ventricular tachycardia (V.T.). The above arrhythmias appeared within five minutes after return to ventilation with room air and continued for 15-22 minutes.

\section{Halothaine 1 Per Cent Group}

Sixteen animals were ventilated with halothane one per cent for fifteen minutes and were then given aminophylline. Heart rate increased $74 \pm 16.9$ from $134 \pm$ 24.8 (excluding three cases of ventricular fibrillation (V.F.). The incidence and severity of arrhythmias are shown in Table I. Three dogs developed M.P.V.C. progressing to V.T. and terminating in V.F. Individual data on the dogs in this group is presented in Table II. Arterial pressure decreased $40 \pm 16.6$ from $131 \pm 22.8$ excluding the animals with ventricular fibrillation. Arterial pressure changes did not differ significantly $(p \leqslant 0.05)$ in the animals developing arrhythmias. A myocardial ischaemic E.C.G. pattern appeared in four animals while they were being ventilated with halothane but disappeared following aminophylline. Arrhythmias were induced with less than $25 \mathrm{mg} . / \mathrm{kg}$. of aminophylline in ten dogs and less than $37.5 \mathrm{mg} . / \mathrm{kg}$. in two others. Ventricular fibrillation developed in one animal when $12.5 \mathrm{mg} . / \mathrm{kg}$. was given.

\section{Deepening Level of Anaesthesia during Arrhythmias}

Five dogs in the group which developed ventricular arrhythmias and one with S.T. from aminophylline-halothane were ventilated with halothane 3 per cent while arrhythmias were occurring (Table III). Within three minutes on halothane 3 per cent, arrhythmias ceased and the dogs were again ventilated with room air. Several minutes later arrhythmias reappeared in the five animals which had previously had ventricular arthythmias, starting with U.P.V.C. progressing to M.P.V.C. and occasional bursts of V.T. The animal with S.T. (dog 40) after aminophylline also developed U.P.V.C., M.P.V.C., and V.T. The arrhythmias lasted from one to eighteen minutes, terminating with U.P.V.C. and then normal sinus rhythm (N.S.R.). Halothane 3 per cent was again administered following termination of arrhythmias, and the results are shown in Table III under the second trial. Four of the animals immediately developed arrhythmias lasting for 


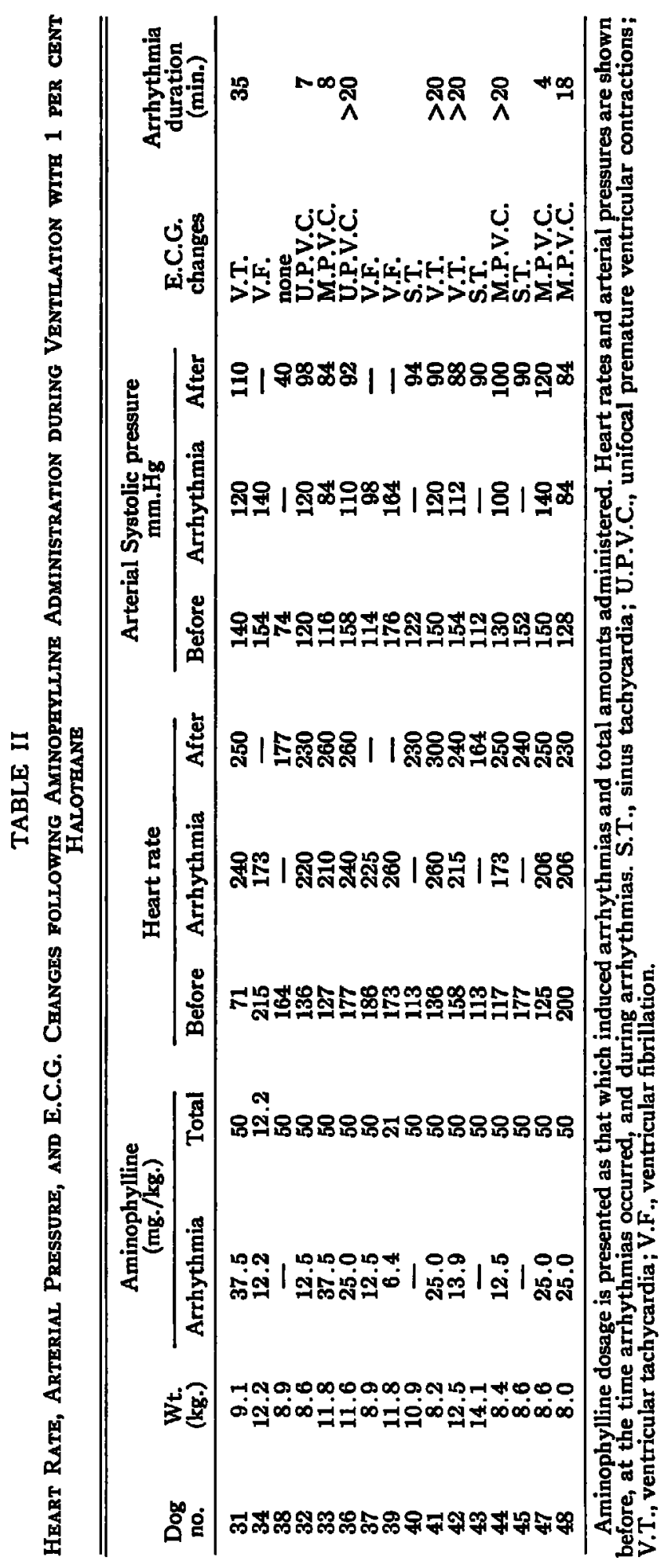




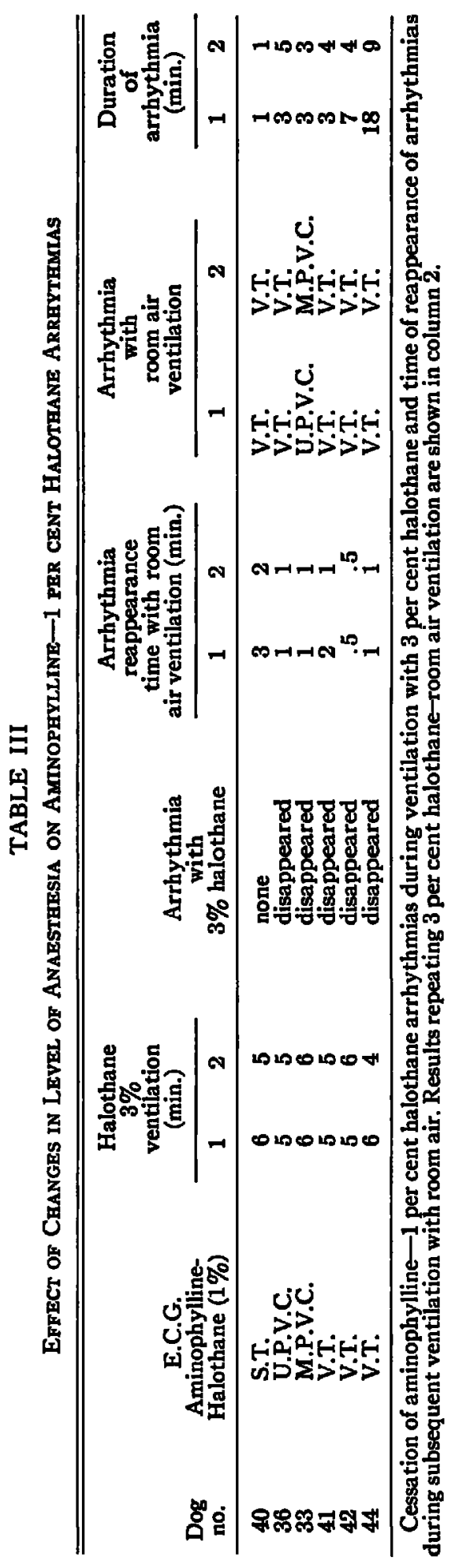


several seconds, which then reverted to N.S.R. When halothane was discontinued and the animals subsequently returned to ventilation with room air, U.P.V.C., M.P.V.C., and occasional bursts of V.T. were found.

\section{Discussion}

Positive inotropic and chronotropic activity of methylxanthine derivatives has been recognized since the past century, ${ }^{12}$ and more recently has been demonstrated by other investigators. ${ }^{13-14}$ Ventricular arrhythmias have been described as occurring with toxic doses of methylxanthines ${ }^{12}$ or with smaller doses in combination with sympathomimetic amines. ${ }^{6-7}$ In another study arrhythmias did not develop in dogs pretreated with reserpine or in "spinal" animals with intravenous caffeine or theophylline $50-200 \mathrm{mg} . / \mathrm{kg}$. until the animals were subsequently given epinephrine $5 \mu \mathrm{g} . / \mathrm{kg} .{ }^{7}$ It was concluded that methylxanthines sensitize the myocardium to epinephrine and that the presence of catecholamine is necessary for development of cardiac arrhythmias with doses of methylxanthines as large as $200 \mathrm{mg} . / \mathrm{kg}$. We have also shown that with halothane anaesthesia ventricular arrhythmias were more severe when administration of the sympathomimetic amines ephedrine and isoproterenol were preceded by aminophylline. ${ }^{11}$ The above data suggest that arrhythmias with halothane and aminophylline in the present studies may be related to the presence of catecholamine. Sympathoadrenal stimulation, however, has been shown to be weak with halothane when compared to ether and cyclopropane. ${ }^{15-17}$ In addition, cardiovascular responses ${ }^{18,19}$ and contractile responses of excised aortic tissue $e^{20}$ to catecholamine have been reported to have diminished during halothane anaesthesia. Halothane, however, has the property of cardiac sensitization to certain sympathomimetic amines. Sensitization of the heart to arrhythmias by agents which produce myocardial depression has been a subject of concern. ${ }^{21}$ In the present studies the apparent protection afforded by deep halothane anaesthesia to aminophylline-induced arrhythmias seems paradoxical but may parallel the decreased cardiac or vascular tissue responses ${ }^{18-20}$ to catecholamines as reported by other investigators.

Termination of arrhythmias by deepening the level of anaesthesia with halothane has been reported by Muir et al. ${ }^{22}$ who found arrhythmias in cats breathing halothane 1 per cent but a sudden cessation when the concentration was increased to 2-3 per cent. Appearance of arrhythmias was associated with hypercarbia, and cessation also followed return of arterial $\mathrm{P}_{\mathrm{CO}_{2}}$ to normal. Purchase has reported that cardiac arrhythmias during halothane anaesthesia in cats were terminated temporarily by an increase in the concentration of inspired halothane but reappeared within five minutes. ${ }^{23}$ Disappearance of arrhythmias seems unrelated to a reduction in arterial pressure or an alteration in blood gases. Johnstone reported that arrhythmias did not occur in deeply anaesthetized and well-ventilated patients but were provoked in lightly anaesthetized subjects by carbon dioxide retention, intravenous injections of atropine, or surgical stimulation.24 Black et $a l .{ }^{25}$ on the other hand, found that the threshold at which hypercarbia induced arrhythmias in humans was not consistently influenced by the depth of halothane anaesthesia. 
A significant difference in the level of blood pressure was noted between the 1 per cent and 3 per cent halothane groups prior to the administration of aminophylline $(0.01<p<0.02)$. It could not, however, be concluded from our studies that the level of blood pressure influenced the incidence or severity of arrhythmias. Although limitation of blood pressure rise after sympathomimetic amines during hydrocarbon anaesthesia has been shown to prevent arrhythmias, ${ }^{26,27}$ arrhythmias have also been reported during falls in blood pressure. ${ }^{28-30}$

\section{Summary}

Intravenous administration of aminophylline to dogs anaesthetized with 1 per cent halothane resulted in ventricular arrhythmias in 12 of 16 animals (ventricular fibrillation in three animals). Halothane-aminophylline arrhythmias disappeared when the animals were ventilated with 3 per cent halothane but reappeared when the animals were subsequently ventilated with room air. Arrhythmias did not occur when aminophylline was given to animals ventilated with 3 per cent halothane or to dogs anaesthetized with pentobarbital. Following administration of aminophylline one out of ten unanaesthetized dogs and two of six animals ventilated with 3 per cent ether developed short periods of multifocal premature ventricular contractions. A possible explanation of the data obtained is presented.

\section{RÉSUMÉ}

L'administration d'aminophylline par voie endoveineuse à des chiens anesthésiés avec 1 pour cent de fluothane a entrainé des arythmies ventriculaires chez 12 des 16 animaux et une fibrillation ventriculaire, chez trois. Les arythmies fluothaneaminophylline sont disparues lorsque, subséquemment, nous avons ventilé les animaux avec l'air de la pièce. Nous n'avons pas observé d'arythmies lorsque nous avons donné l'aminophylline à des animaux ventilés avec 3 pour cent d'halothane ou à des chiens anesthésiées avec du pentobarbital. A la suite de l'administration d'aminophylline un sur dix des chiens non anesthésiés et deux sur six des animaux ventilés avec 3 pour cent d'éther ont présenté de courtes périodes de contractions ventriculaires prématurées multifocales. Nous présentons une explication possible des résultats obtenus.

\section{ACKNOWLEDGMENT}

This research was supported by Grant H-5678 from the National Institutes of Health, U.S. Public Health Service.

\section{REFERENCES}

1. Wylie, W. D. \& Churchml-Davmoson, H. C. A Practice of Anaesthesia. 1st ed., Chicago: Year Book Publishers Inc. (1961), p. 28.

2. Evans, F. T. \& Gray, C. General Anaesthesia, vol. 2. 1st ed., London: Butterworth \& Co. (1959), p. 337.

3. Antusio, J. F. \& Mazzia, V. D. B: Practical Anesthesiology. Ist ed, St. Louis: C. V. Mosby Co. (1962), p. 224. 
4. Converse, J. G. \& Smotrmin, M. M. Anesthesia and the Asthmatic. Anesth. \& Analg. 40: 336 (1961).

5. Shnmer, S. M. \& Pappen, E. M. Anesthesia for the Asthmatic Patient. Anesthesiology. 22: 886 (1961).

6. Mrzmasarma, G. Spunti Patogenetic Sulle Aritmie Sperimental da Caffeina-Adrenalina. Boll. Soc. Ital, Biol. Sper. 32: 1637 (1956).

7. UEDA, I.; LoEming, R. W.; \& UEYAMA, H. Relationship Between Sympathomimetic Amines and Methylxanthines Inducing Cardiac Arrhythmias. Anesthesiology 22: 926 (1961).

8. Barace, A. L. Remissions in Bronchial Asthma and Hypertrophic Pulmonary Emphysema. J.A.M.A. 147: 730 (1951).

9. GAY, L. N. The Diagnosis and Treatment of Bronchial Asthma. Baltimore: Williams \& Willoins Co. (1946), p. 197.

10. Abramson, H. A. Treatment of Asthma. Baltimore: Williams \& Wilkins Co. (1951), p. 161.

11. TAKAORT, M. \& Loemnne, R. W. Ventricular Arrhythmias during Halothane Anesthesia: Effect of Isoproterenol, Aminophylline, and Ephedrine. Canad. Anaesth. Soc. J. 12: 275 (1965).

12. Soldman, T. A Manual of Pharmacology. 8th ed., Philadelphia: Saunders (1957), p. 258.

13. Hardman, H. F. Molecular Form of Theophylline Responsible for Inotropic Activity. Circulation Res. 10: 598 (1962).

14. Dawere, H. \& Becker, G. Die Wirkung von Sympathicomimetica in Kombination mit Xanthinderivaten am isolierten Meershweinchenherzen nach Lagendorf. Arch. Int. Pharmacodyn. 122: 357 (1959).

15. Pruce, H. L.; Linde, H. W.; Jones, R. E.; Brack, G. W.; \& Price, M. L. Sympathoadrenal Responses to General Anesthesia in Man and Their Relation to Hemodynamics. Anesthesiology. 20: 563 (1959).

16. Hameingerg, W.; Sprouse, J. H.; Mafaffey, J. E.; \& Ruchardson, J. A. Catechol Levels during Light and Deep Anesthesia. Anesthesiology. 21: 297 (1960).

17. Mrran, R. A. \& Morris, M. E. Sympatho-adrenal Responses during General Anesthesia in the Dog and Man. Canad. Anaesth. Soc. J. 8: 356 (1961).

18. Nayzer, W. G. The Action of Fluothane, Chloroform, and Hypothermia on the Heart. Austr. J. Exp. Biol. Med. Sci. 37: 279 (1959).

19. Black, G. W. \& McArble, L. The Effects of Halothane on the Peripheral Circulation in Man. Brit. J. Anaesth. 34: 2 (1962).

20. Pruce, M. L. \& Price, H. L. Effect of General Anesthetics on Contractile Responses of Rabbit Aortic Strips. Anesthesiology. 23: 16 (1962).

21. Rmken, W. F.; DePmerqe, F.; Robimrs, J.; Rox, B. B.; \& Remcr, J. The Epinephrine and Hydrocarbon-epinephrine Disturbance in the Cat. J. Pharmacol. \& Exp. Therap. 114: 1 (1955).

22. Mum, B. J.; HaL, L. W.; \& Lrrrueworth, M. C. G. Cardiac Irregularities in Cats under Halothane Anaesthesia. Brit. J. Anaesth. 31 : 488 (1959).

23. Purchase, I. F. H. Cardiac Arrhythmias Occurring during Halothane Anaesthesia in Cats. Brit. J. Anaesth. 38: 13 (1966).

24. Jomnstone, M. Halothane: The First Five Years. Anesthesiology. 22: 591 (1961).

25. Black, G. W.; Lnnoe, H. W.; Drmps, R. D.; \& Price, H. L. Circulatory Changes Accompanying Respiratory Acidosis during Halothane Anaesthesia in Man. Brit. J. Anaesth. 31: 238 (1959).

26. Moe, G. K.; Malton, S. D.; Renncax, B. R.; \& Frexburger, W. A. Role of Arterial Pressure in Induction of Idioventricular Rhythms under Cyclopropane Anesthesia. J. Pharmacol. \& Exp. Therap. 93: 319 (1948).

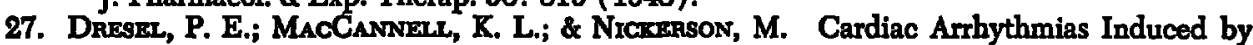
Minimal Doses of Epinephrine in Cyclopropane-Anesthetized Dogs. Circulation Res. 8: 948 (1960).

28. Cummengs, J. R. \& Hays, W. Cardiovascular Studies of Adrenergic and Ganglionic Stimulating Drugs Administered during Cyclopropane. Anesthesiology. 17: 314 (1956).

29. Nickzrson, M. \& Nomaguch, G. Mechanism of Dibenamine Protection against Cyclopropane-Epinephrine Cardiac Arrhythmias. J. Pharmacol. Exper. Therap. 95: 1 (1949).

30. Snzbeckgk, K. L.; Bàmozta, B. J.; Krazmigr, R.; \& Orth, O. S. Ventricular Tachycardia Produced by Metaraminol during Cyclopropane Anesthesia in Dogs. Anesthesiology. 22: 555 (1961). 